\title{
APAKAH KETENTUAN PAJAK PENGHASILAN ATAS REVALUASI ASET TETAP SEJALAN DENGAN KONVERGENSI IFRS?
}

\author{
Emik Suyani \\ Politeknik Keuangan Negara STAN \\ emik.suyani2017@gmail.com
}

\section{INFORMASI ARTIKEL}

Diterima Pertama

20-11-2017

Dinyatakan Diterima

22-11-2017

KATA KUNCl: income tax, revaluation of fixed assets, convergence, IFRS

\section{ABSTRACT}

The aim of this study is to analyse the appropriateness of imposing income tax on the revaluation of fixed assets by firstly confirming to the concept of income according to both accounting and tax purposes. This study also will analyse the principle of income and the commitment to support the IFRS convergence dealing with the issue of the income tax imposition of fixed assets revaluation. This study conducts explanatory and descriptive research by specifically collecting and analysing the data in forms of the Basis of Preparation and Presentation of Financial Statements, Statement of Financial Accounting Standard 1 and 16, tax regulations relating to fixed asset revaluation, as well as textbooks and journals. From this study, it is concluded that for accounting purpose, the excess of fixed asset revaluation will be recognized as income in the form of unrealized gain, while for tax purpose, this excess will not be treated as income because it breaks the principle of realized transaction in terms of imposing income tax (there is no transaction with external party). Tax regulation of imposing income tax on the excess of the revaluation of fixed asset is required to be reviewed providing that it is not appropriate with the principle of income recognition as well as it is unfitted with the commitment of Indonesia to support the IFRS convergence.

\section{ABSTRAK}

Penelitian ini bertujuan untuk menganalisis selisih lebih revaluasi aset tetap berdasarkan konsep penghasilan menurut akuntansi dan pajak serta pengenaan Pajak Penghasilan atas selisih lebih revaluasi aset tetap tersebut dikaitkan dengan prinsip penghasilan dan komitmen untuk melakukan konvergensi IFRS. Penelitian ini bersifat kualitatif deskriptif dan eksplanatori. Analisis dilakukan terhadap data penelitian yang mencakup Dasar Penyusunan dan Penyajian Laporan Keuangan, PSAK 1, PSAK 16, peraturan perpajakan yang terkait dengan revaluasi aset tetap, serta buku teks dan jurnal. Hasil penelitian menunjukkan bahwa dari sisi akuntansi, selisih lebih revaluasi aset tetap merupakan penghasilan yang berupa keuntungan yang belum direalisasi. Sedangkan dari sisi pajak, selisih lebih revaluasi bukan penghasilan karena belum direalisasi (tidak ada transaksi eksternal). Peraturan perpajakan mengenai pengenaan pajak atas selisih lebih revaluasi aset tetap untuk tujuan perpajakan yang berlaku saat ini perlu dikaji ulang karena tidak sesuai dengan prinsip penghasilan serta tidak selaras dengan komitmen Indonesia untuk melakukan konvergensi IFRS. 


\section{PENDAHULUAN}

Perkembangan kegiatan ekonomi dan globalisasi menuntut adanya suatu standar akuntansi internasional yang dapat diterima dan dapat dipahami secara internasional. Oleh karena itu, muncullah suatu standar internasional, yaitu International Financial Reporting Standards (IFRS) yang kemudian dijadikan sebagai pedoman penyajian laporan keuangan di berbagai negara (Juanda, 2012).

Indonesia; sebagai bagian dari bisnis global telah berkomitmen melakukan konvergensi IFRS terhadap Pernyataan Standar Akuntansi Keuangan (PSAK). Budi (2012) menyatakan bahwa perkembangan konvergensi IFRS di Indonesia dimulai dari kesepakatan G-20 di Pittsburg pada tanggal 24-25 September 2009. Isi kesepakatan itu di antaranya menyatakan bahwa otoritas yang mengawasi peraturan akuntansi internasional harus meningkatkan standar global pada Juni 2011 untuk mengurangi kesenjangan peraturan di antara negara-negara anggota G-20.

Penerapan konvergensi IFRS sangat berpengaruh pada iklim dunia bisnis di Indonesia. Dengan dibuatnya satu standar akuntansi yang sama dan digunakan oleh seluruh negara akan semakin mendorong investor untuk masuk dalam pasar modal seluruh dunia. Hal ini dikarenakan mutu laporan keuangan yang dihasilkan memiliki kredibilitas tinggi, pengungkapan yang lebih luas, informasi keuangan yang relevan dan akurat serta dapat diperbandingkan dan satu lagi yang terpenting adalah dapat diterima secara internasional dan mudah untuk dipahami (Juanda, 2012). Lebih lanjut, Juanda (2012) menyatakan bahwa tujuan konvergensi IFRS adalah agar laporan keuangan berdasarkan PSAK tidak memerlukan rekonsiliasi lagi dengan laporan keuangan berdasarkan IFRS. Dengan demikian diharapkan dapat meningkatkan kegiatan investasi secara global, memperkecil biaya modal (cost of capital), serta lebih meningkatkan transparansi perusahaan dalam penyusunan laporan keuangan.

Namun, pelaksanaan konvergensi PSAK tidaklah mudah. Saputra dan Hermawan (2012) menyatakan bahwa salah satu alasan yang cukup menghambat konvergensi IFRS adalah kurang cepatnya respon regulator perpajakan (Direktorat Jenderal Pajak) dalam menanggapi masa transisi ini. PSAK saat ini sudah mengalami peningkatan yang sangat pesat, sementara itu peraturan perpajakan sangat tertinggal jauh dalam hal penggunaan dasar akuntansinya. Penyesuaian antara konvergensi PSAK dengan peraturan perpajakan merupakan hal yang penting mengingat bahwa konvergensi PSAK akan berdampak pada perpajakan. Budi (2012) melakukan penelitian tentang pengaruh konvergensi IFRS terhadap perpajakan di Indonesia. Hasilnya menunjukkan bahwa ada enam PSAK yang diadopsi dari IFRS dan memberikan pengaruh terhadap perpajakan. PSAK tersebut adalah [1] PSAK 10 (Revisi 2010): Pengaruh Perubahan Kurs Valuta Asing, [2] PSAK 13 (Revisi 2011): Properti Investasi, [3] PSAK 16 (Revisi
2011): Aset Tetap, [4] PSAK 22 (Revisi 2010): Kombinasi Bisnis, [5] PSAK 25 (Revisi 2009): Kebijakan Akuntansi, Perubahan Estimasi Akuntansi, dan Kesalahan, dan [6] PSAK 30 (Revisi 2011): Sewa.

Salah satu perbedaan yang mendasar antara PSAK konvergen IFRS dengan peraturan perpajakan adalah PSAK konvergen IFRS mengizinkan entitas untuk memilih model biaya atau model revaluasi untuk penilaian aset tetapnya sedangkan peraturan perpajakan hanya memperkenankan model biaya. Penggunaan model revaluasi untuk tujuan perpajakan berdampak pada dikenakannya Pajak Penghasilan atas selisih lebih revaluasi aset tetap. Ketentuan ini diatur dalam Peraturan Menteri Keuangan Nomor 79/PMK.03/2008 tentang Penilaian Kembali Aset Tetap Perusahaan untuk Tujuan Perpajakan. Peraturan ini disinyalir dapat menghambat penerapan model revaluasi sesuai PSAK konvergen IFRS. Purwanti et.al (2017) telah melakukan penelitian tentang motivasi penggunaan model revaluasi oleh perusahaan yang terdaftar di Bursa Efek Indonesia selama rentang waktu 2008-2016. Hasilnya menunjukkan bahwa hanya 76 dari total 531 perusahaan yang terdaftar di Bursa Efek Indonesia yang menggunakan model revaluasi dalam penilaian aset tetapnya. Menariknya, salah satu faktor yang mempengaruhi dilakukannya revaluasi aset tetap adalah insentif pajak. Ini tercermin dari meningkatnya jumlah perusahaan yang melakukan revaluasi aset tetap selama tahun 2015-2016. Selama 2008-2014 perusahaan yang melakukan revaluasi aset tetap ada 24 perusahaan sedangkan selama 2015-2016 meningkat menjadi 52 perusahaan. Pada tahun 20152016 terjadi penurunan tarif pajak penghasilan atas selisih lebih revaluasi aset tetap dari semula $10 \%$ menjadi 3\%,4\%, atau 6\%. Penelitian Purwanti et.al. (2017) membuktikan bahwa peraturan perpajakan dapat mempengaruhi motivasi perusahaan untuk melakukan penilaian aset tetap sesuai PSAK konvergen IFRS.

Selain disinyalir dapat menghambat penerapan PSAK konvergen IFRS, pengenaan Pajak Penghasilan atas selisih lebih revaluasi aset tetap juga menjadi topik yang menarik jika dilihat dari sisi konsep penghasilan. Di Indonesia, pengenaan Pajak Penghasilan atas selisih lebih revaluasi aset tetap untuk tujuan perpajakan disebabkan peraturan perpajakan mengakui penilaian aset tetap berdasarkan model biaya sehingga jika entitas sebagai Wajib Pajak menggunakan model revaluasi untuk tujuan perpajakan dan terdapat kenaikan nilai aset tetap maka entitas sebagai Wajib Pajak dianggap memperoleh penghasilan sehingga layak untuk dikenai Pajak Penghasilan. Terdapat beberapa pendapat mengenai pengenaan Pajak Penghasilan terhadap selisih lebih revaluasi aset tetap. Kwall (2010) berpendapat bahwa Pajak Penghasilan sudah seharusnya dikenakan pada saat terjadi selisih lebih nilai aset (asset appreciation) dengan mempertimbangkan kenaikan nilai ekuitas serta masalah efisiensi pengenaan pajak tanpa harus menunggu sampai dengan terjadi realisasi penjualan. Sementara itu, Organisasi untuk Kerja Sama dan 
Pembangunan Ekonomi (OECD - Organisation for Economic Co-operation and Development) menyatakan bahwa pada dasarnya pajak penghasilan dikenakan atas realisasi penghasilan bersih oleh Wajib Pajak dalam satu periode penghasilan.

Berdasarkan uraian di atas, perumusan masalah dalam penelitian ini adalah:

a. Apakah terdapat perbedaan penilaian aset tetap menurut PSAK konvergen IFRS dengan peraturan perpajakan Indonesia?

b. Apakah terdapat perbedaan pengakuan penghasilan menurut PSAK konvergen IFRS dengan Indonesia?

c. Apakah pengenaan Pajak Penghasilan atas selisih lebih revaluasi aset tetap telah sesuai dengan konsep penghasilan menurut peraturan perpajakan Indonesia?

d. Apakah pengenaan Pajak Penghasilan atas selisih lebih revaluasi aset tetap telah selaras dengan konvergensi IFRS?

Tulisan ini bertujuan untuk menganalisis lebih lanjut mengenai:

a. perlakuan penilaian aset tetap menurut PSAK konvergen IFRS dan peraturan perpajakan Indonesia;

b. konsep pengakuan penghasilan menurut PSAK konvergen IFRS dan peraturan perpajakan;

c. pengenaan Pajak Penghasilan atas selisih lebih revaluasi aset tetap untuk tujuan perpajakan berdasarkan konsep penghasilan; dan

d. pengenaan Pajak Penghasilan dalam perspektif konvergensi IFRS.

\section{LANDASAN TEORI}

\subsection{PSAK Konvergen IFRS}

Sejak Indonesia memutuskan melakukan konvergensi IFRS maka PSAK mengacu pada IFRS. Tiga ciri utama IFRS sebagai standar internasional menurut Martani et.al (2014) sebagai berikut:

a. Principle-Based

Standar yang menggunakan principles-based hanya mengatur hal-hal yang pokok dalam standar sedangkan prosedur dan kebijakan detail diserahkan kepada pemakai. Standar mengatur prinsip pengakuan sesuai substansi ekonomi, tidak didasarkan pada ketentuan detail dalam atribut kontrak perjanjian. Sedangkan standar yang rulebased memuat ketentuan pengakuan akuntansi secara detail. Keunggulan pendekatan ini akan menghindari dibuatnya perjanjian atau transaksi mengikuti peraturan dalam konsep pengakuan.

b. Nilai Wajar (Fair Value)

Standar akuntansi banyak menggunakan konsep nilai wajar (fair value). Penggunaan nilai wajar untuk meningkatkan relevansi informasi akuntansi untuk pengambilan keputusan. Informasi nilai wajar lebih relevan karena menunjukkan nilai terkini. Hal ini sangat bertolak belakang dengan konsep harga perolehan yang mendasarkan penilaian pada nilai perolehan pertama (historical cost). Banyak pengakuan akuntansi saat ini yang dasar penilaiannya masih menggunakan historical cost. IFRS membuka peluang penggunaan nilai wajar yang lebih luas dan untuk beberapa item seperti aset tetap dan aset tidak berwujud, dibuka opsi penggunaan nilai wajar selain nilai perolehan.

c. Pengungkapan

Mengharuskan lebih banyak pengungkapan (disclosure) dalam laporan keuangan. Pengungkapan diperlukan agar pengguna laporan keuangan dapat mempertimbangkan informasi yang relevan dan perlu diketahui terkait dengan apa yang dicantumkan dalam laporan keuangan dan kejadian penting yang terkait dengan item tersebut.

\subsection{Konsep Penghasilan Menurut Akuntansi}

Menurut Kerangka Dasar Penyusunan dan Penyajian Laporan Keuangan (Penyesuaian 2014), definisi penghasilan (income) meliputi baik pendapatan (revenues) maupun keuntungan (gains). Pendapatan timbul dalam pelaksanaan aktivitas perusahaan yang biasa dan dikenal dengan sebutan yang berbeda seperti penjualan, penghasilan jasa (fees), bunga, dividen, royalti, dan sewa. Keuntungan mencerminkan pos lainnya yang memenuhi definisi penghasilan dan mungkin timbul atau mungkin tidak timbul dalam pelaksanaan aktivitas entitas yang biasa. Keuntungan meliputi, sebagai contoh pos yang timbul dalam pengalihan aset tidak lancar. Definisi penghasilan juga mencakup keuntungan yang belum direalisasi, sebagai contoh yang timbul dari revaluasi sekuritas yang dapat dipasarkan (marketable) dan dari kenaikan jumlah aset jangka panjang.

Lebih lanjut, dalam paragraf 92 Kerangka Dasar Penyusunan dan Penyajian Laporan Keuangan (Penyesuaian 2014) disebukan bahwa penghasilan diakui dalam laporan laba rugi ketika kenaikan manfaat ekonomik di masa depan yang berkaitan dengan kenaikan aset atau penurunan liabilitas telah terjadi dan dapat diukur dengan andal. Ini berarti pengakuan penghasilan terjadi bersamaan dengan pengakuan kenaikan aset atau penurunan liabilitas (sebagai contoh kenaikan bersih aset yang timbul dari penjualan barang atau jasa atau penurunan liabilitas yang timbul dari pembebasan pinjaman yang masih harus dibayar).

Sebelum Indonesia melakukan konvergensi IFRS, PSAK menggunakan prinsip laba rugi yang konservatif. Setelah melakukan konvergensi IFRS, PSAK menggunakan prinsip laba rugi yang komprehensif (Martani et.al, 2014). Prinsip konservatisme (kehatihatian) mengakui segera kerugian dan menangguhkan laba sampai benar-benar terealisasi. Pada awalnya konsep dasar konservatisme diperkenalkan dan dijadikan sebagai salah satu kerangka konseptual (conseptual framework) dalam penyusunan laporan keuangan sebagai bagian dari usaha untuk mengimbangi adanya konsep optimisme yang berlebihan dalam membaca laporan keuangan. Hal ini dijadikan kesepakatan mengingat bahwa konsekuensi 
dari konsep optimisme (menyajikan kelebihan laba) lebih membahayakan keberlangsungan usaha (going concern) dibandingkan jika menyajikan secara konservatif, yaitu menyajikan kurang laba. Konsekuensi tersebut antara lain risiko pembayaran serta pembagian dividen yang lebih tinggi. Namun demikian, dalam perjalannya penerapan konsep ini semakin mempersulit untuk menilai perusahaan secara benar. Lebih jauh, penyajian laporan keuangan dengan konsep konservatisme justru menciptakan keraguan dalam kualitas pelaporan, sehingga kurang dapat mendukung dalam pengambilan keputusan dan dapat menyesatkan pihak pengguna laporan keuangan (Basu, 2009). Demikian juga dengan perkembangan ekonomi, bermunculannya perusahaan perusahaan multinasional, perkembangan ilmu pengetahuan dan teknologi, membuat prinsip-prinsip dalam US GAAP terlalu konservatif untuk mengevaluasi suatu operasi perusahaan dan biaya historis sudah tidak dapat menggambarkan keadaan aset suatu perusahaan sebenarnya (Martani et.al, 2014). Satu ilustrasi sederhana, seringkali kita mendapati kenaikan secara drastis nilai aset tetap tanah dan bangunan di kotakota besar di Indonesia. Misalnya, PT ABC membeli tanah dan melakukan pembangunan sepuluh tahun yang lalu senilai Rp500 juta dan harga pasar sekarang nilai tanah di wilayah tersebut melonjak drastis menjadi senilai Rp5 miliar. Jika perusahaan tetap menggunakan konsep konservatisme, penyajian laporan keuangannya tersebut sudah tidak relevan dengan kondisi yang sesungguhnya.

Oleh karena itu muncul solusi baru untuk mengikuti perkembangan berbagai hal yang menuntut arus informasi yang berkualitas berupa konsep laba rugi komprehensif yang dapat menjawab semua pertanyaan tersebut (Martani et.al, 2014). Total laba rugi komprehensif terdiri dari komponen laba rugi dan penghasilan komprehensif lain. Penghasilan komprehensif lain menurut PSAK 1 (Penyesuaian 2014) berisi pos-pos penghasilan dan beban (termasuk penyesuaian reklasifikasi) yang tidak diakui dalam laba rugi sebagaimana disyaratkan atau diizinkan oleh SAK. Komponen penghasilan komprehensif lain mencakup: (a) perubahan dalam surplus revaluasi aset tetap dan aset tidak berwujud, (b) pengukuran kembali program imbalan pasti, (c) keuntungan dan kerugian yang timbul dari penjabaran laporan keuangan dari kegiatan usaha luar negeri (d) keuntungan dan kerugian dari pengukuran kembali aset keuangan sebagai tersedia untuk dijual, dan (e) bagian efektif dari keuntungan dan kerugian instrumen lindung nilai dalam rangka lindung nilai arus kas. Sebagian komponen penghasilan komprehensif lainnya merupakan konsekuensi diterapkannya prinsip fair value. Penerapan prinsip fair value mengharuskan entitas melakukan penilaian aset sesuai harga pasar pada saat pelaporan. Selisih lebih antara harga pasar dengan nilai terbawa (nilai sisa buku) merupakan keuntungan yang belum direalisasi yang disajikan sebagai penghasilan komprehensif lainnya.

\subsection{PSAK dalam Peraturan Perpajakan}

Penjelasan Pasal 28 ayat (7) Undang-Undang Nomor 28 Tahun 2007 tentang Perubahan Ketiga Atas Undang-Undang Nomor 6 Tahun 1983 tentang Ketentuan Umum dan Tata Cara Perpajakan, yang selanjutnya disebut UU KUP 2007 menyatakan bahwa:

“... Dengan demikian, pembukuan harus diselenggarakan dengan cara atau sistem yang lazim dipakai di Indonesia, misalnya berdasarkan Standar Akuntansi Keuangan, kecuali peraturan perundangundangan perpapajakan menentukan lain."

Pengaturan dalam ketentuan di atas dimaksudkan agar berdasarkan pembukuan tersebut dapat dihitung besarnya pajak yang terutang. Ketentuan di atas juga menjadi pedoman bagi semua Wajib Pajak untuk mengacu pembukuannya ke PSAK yang diterbitkan oleh IAI. Acuan metode pembukuan dimungkinkan tidak merujuk ke PSAK, tetapi ke peraturan perpajakan sepanjang ketentuan peraturan perpajakan mengatur secara tersendiri (Budi, 2012).

\subsection{Akuntansi Aset Tetap Menurut PSAK dan Peraturan Perpajakan}

Perlakuan akuntansi aset tetap diatur dalam PSAK 16 (Penyesuaian 2014): Aset Tetap. Di sisi lain, peraturan perpajakan mengatur secara tersendiri untuk akuntansi aset tetap dalam Pasal 11 UndangUndang Nomor 36 Tahun 2008 tentang Perubahan Keempat atas Undang-Undang Nomor 7 Tahun 1983 tentang Pajak Penghasilan, yang selanjutnya disebut UU Pajak Penghasilan.

Budi (2012) membuat perbandingan perbedaan perlakuan akuntansi dan pajak aset tetap sebagaimana dalam Tabel 1 (lihat Lampiran).

\subsection{Pengenaan Pajak atas Selisih Lebih Revaluasi Aset Tetap}

Berdasarkan Tabel 1, diketahui bahwa salah satu perbedaan perlakuan akuntansi aset tetap adalah saat pengukuran setelah pengakuan awal. PSAK mengizinkan diterapkan model biaya atau model revaluasi. Sedangkan peraturan perpajakan menggunakan model biaya. Model revaluasi diizinkan sepanjang diajukan kepada Dirjen Pajak dan Dirjen Pajak berwenang menerbitkan surat keputusan.

Dalam hal entitas sebagai Wajib Pajak menggunakan model revaluasi aset tetap untuk tujuan perpajakan, Wajib Pajak akan dikenakan Pajak Penghasilan atas selisih lebih revaluasi. Pasal 19 UU Pajak Penghasilan mengatur bahwa Menteri Keuangan berwenang menetapkan peraturan tentang revaluasi aset tetap dan mengenakan pajak dengan tarif tersendiri yang diatur dengan Peraturan Menteri Keuangan.

Ketentuan lebih lanjut tentang revaluasi aset tetap untuk tujuan perpajakan diatur dalam Peraturan Menteri Keuangan Nomor 79/PMK.03/2008, yang dapat diringkas dalam Tabel 2 (lihat Lampiran).

Khusus untuk revaluasi aset tetap untuk tujuan perpajakan yang diajukan selama tahun 2015-2016 terjadi penurunan tarif menjadi sebesar 3\% (untuk pengajuan sampai dengan 31 Desember 2015), 4\% 
(untuk pengajuan 1 Januari sampai dengan 30 Juni 2016), dan 6\% (untuk pengajuan 1 Juli sampai dengan 31 Desember 2016) sesuai Peraturan Menteri Keuangan Nomor 191/PMK.010/2015.

\subsection{Pengenaan Pajak atas Pengalihan Hak atas Tanah dan/atau Bangunan}

Dalam hal Wajib Pajak mengalihkan aset tetap berupa tanah dan/atau bangunan, Wajib Pajak dikenakan Pajak Penghasilan Final sebagaimana diatur dalam Pasal 4 ayat (2) UU Pajak Penghasilan. Peraturan Pemerintah Nomor 34 Tahun 2016 mengatur lebih lanjut pengenaan pajak atas transaksi pengalihan hak atas tanah dan/atau bangunan, yang diringkas dalam Tabel 3 (lihat Lampiran).

\subsection{Konsep Penghasilan sebagai Objek Pajak}

Di Indonesia, Wajib Pajak dikenai pajak atas transaksi yang menimbulkan penghasilan baginya. Dengan demikian, yang dijadikan objek pajak adalah penghasilan Wajib Pajak, bukan kekayaan atau pengeluaran konsumsinya (Markus dan Yujana, 2004).

Definisi penghasilan menurut Pasal 4 ayat (1)

UU Pajak Penghasilan adalah:

"setiap tambahan kemampuan ekonomis yang diterima atau diperoleh Wajib Pajak, baik yang berasal dari Indonesia maupun dari luar Indonesia, yang dapat dipakai untuk konsumsi atau untuk menambah kekayaan Wajib Pajak yang bersangkutan, dengan nama dan dalam bentuk apa pun..."

Definisi penghasilan menurut Pasal 4 ayat (1) UU Pajak Penghasilan mengandung lima unsur pokok (Markus dan Yujana, 2004), yaitu:

a. setiap tambahan kemampuan ekonomis;

b. yang diterima atau diperoleh Wajib Pajak;

c. baik yang berasal dari Indonesia maupun dari luar Indonesia;

d. yang dapat dipakai untuk konsumsi atau untuk menambah kekayaan Wajib Pajak yang bersangkutan; dan

e. dengan nama dan dalam bentuk apapun.

\subsubsection{Pengertian penghasilan sebagai setiap} tambahan kemampuan ekonomis

Pengertian penghasilan sebagai setiap tambahan kemampuan ekonomis diambil UU Pajak Penghasilan dari S-H-S Concept atau Accretion Concept, yaitu definisi ilmu ekonomi perpajakan (fiscal economics) yang diusulkan oleh tiga ekonom, yaitu George Schanz, Robert Murray Haig, dan Henry C. Simons (Markus dan Yujana, 2004). Haig (1921) dalam Markus dan Yujana (2004) mengusulkan pengertian penghasilan untuk keperluan perpajakan sebagai berikut: "income is the money value of net accretion to one's economic power between two points of time (penghasilan adalah nilai berupa uang dari tambahan kemampuan ekonomis neto seseorang antar dua titik waktu)." Simons (1921) dalam Markus dan Yujana (2004) mendefinisikan penghasilan sebagai berikut: "personal income may be defined as the algebraic sum of (1) the market value of rights exercised in consumption and (2) the change in the value of the store of property rights between the beginning and end of the period in question (penghasilan adalah jumlah aljabar dari (1) nilai pasar dari hak-hak yang dikonsumsi dan (2) perubahan nilai dari hak atas kekayaan yang dimiliki yang terjadi antara awal dan akhir periode."

Definisi penghasilan menurut Accretion Concept menimbulkan dua kesulitan utama, yaitu kesulitan mengukur nilai uang dan kesulitan menentukan tingkat harga. Oleh karena itu, Mansury mendefinisikan penghasilan untuk kepentingan perpajakan Indonesia sebagai berikut: "penghasilan adalah tambahan kemampuan seseorang untuk memenuhi kebutuhan ekonomisnya dalam suatu periode tertentu, sepanjang tambahan kemampuan itu berupa uang atau dapat dinilai dengan uang (Markus dan Yujana, 2004).

Apabila definisi penghasilan menurut Accretion Concept diambil sepenuhnya, akan terdapat kesulitan dalam pelaksanaan pengenaan pajak karena definisi penghasilan tersebut mencakup pengertian penghasilan yang belum direalisasikan. Accretion Concept menganggap bahwa kenaikan nilai harta yang kita miliki, walaupun harta tersebut masih kita pegang dan tidak dialihkan kepemilikannya kepada orang lain (capital appreciation) juga merupakan penghasilan (Markus dan Yujana, 2004).

Oleh karena itu, UU Pajak Penghasilan membatasi pengertian "tambahan kemampuan ekonomis" menurut Accretion Concept dengan menambahkan frasa "yang diterima atau diperoleh Wajib Pajak" (Markus dan Yujana, 2004).

\subsubsection{Konsep realisasi dalam pengakuan penghasilan} Menurut Markus dan Yujana (2004), penambahan frasa "yang diterima atau diperoleh Wajib Pajak" pada pengertian "tambahan kemampuan ekonomis" menyatakan dua hal, yaitu:

a. Tambahan kemampuan ekonomis itu baru dikenai pajak apabila telah direalisasi. Dengan demikian, menurut UU Pajak Penghasilan, tambahan kemampuan ekonomis yang masih dalam bentuk capital appreciation belum merupakan penghasilan karena belum direalisasikan.

b. Tambahan kemampuan ekonomis yang diterima atau diperoleh itu baru dikenai pajak atau baru menjadi penghasilan apabila telah dapat dicatat berdasarkan basis akuntansi yang dipakai oleh Wajib Pajak yang bersangkutan.

Yang menjadi permasalahan, apakah konsep realisasi menurut akuntansi sama atau berbeda dengan konsep realisasi menurut UU Pajak Penghasilan. Markus dan Yujana (2004) membandingkan konsep realisasi menurut akuntansi dan UU Pajak Penghasilan sebagaimana dalam Tabel 4 (lihat Lampiran).

Di Amerika Serikat, realisasi merupakan salah satu prinsip dalam penentuan penghasilan. Dalam kasus Commissioner v Glenshaw Glass Co, Mahkamah Agung (Supreme Court) Amerika Serikat menentukan bahwa penghasilan pada umumnya adalah tambahan kekayaan yang tidak dapat disangkal, secara jelas sudah direalisasi, dan Wajib Pajak telah memiliki penguasaan penuh. Selanjutnya, dalam kasus Helvering $\mathrm{v}$ Bruun Mahkamah Agung menyatakan empat kejadian yang menjadi pemicu realisasi keuntungan atau kerugian, 
yaitu pertukaran properti, pembebasan kewajiban hukum kepada pihak ketiga, pembebasan kewajiban hukum kepada pihak yang menerima properti, dan transaksi menguntungkan lainnya (Kratzke, 2016).

\section{METODE PENELITIAN}

\subsection{Sifat Penelitian}

Penelitian ini bersifat kualitatif deskriptif dan eksplanatori. Maanen (1979) dalam Cooper \& Schindler (2008) mendefinisikan penelitian kualitatif sebagai:

"Qualitative research include an array of interpretive techniques which seek to describe, decode, translate, and otherwise come to terms with the remaining, not the frequency of certain more or less naturally occuring phenomena in the social world."

Penelitian ini menggunakan pendekatan yang bersifat deskriptif dan eksplanatori. Penelitian ini mendeskripsikan data-data yang ada untuk kemudian dijelaskan lebih detail berdasarkan teori yang relevan.

\subsection{Materi Penelitian}

Berdasarkan penjelasan sifat penelitian di atas, materi penelitian ini berupa literatur-literatur sebagai berikut:

a. Kerangka Dasar Penyusunan dan Penyajian Laporan Keuangan (Penyesuaian 2014).

b. PSAK 1 (Penyesuaian 2014): Penyajian Laporan Keuangan.

c. PSAK 16 (Penyesuaian 2014): Aset Tetap.

d. Peraturan perpajakan, yang terkait dengan ketentuan umum dan tata cara perpajakan, Pajak Penghasilan, Pajak Penghasilan atas selisih lebih revaluasi aset tetap dan pengalihan aset tetap.

e. Buku teks dan jurnal.

\subsection{Alat/instrumen Penelitian}

Dalam penelitian kualitatif, mutu alat penelitian terkait erat dengan validitas dan reliabilitas instrumen penelitian. Untuk penelitian kualitatif, instrumen penelitiannya adalah penulis itu sendiri sehingga validasi dilakukan oleh penulis sendiri dengan memperhatikan di antaranya hal-hal sebagai berikut (Budi, 2012):

a. pemahaman penulis terhadap metode penelitian kualitatif

b. penguasaan wawasan penulis terhadap bidang yang diteliti

c. kesiapan penulis untuk memasuki objek penelitian.

\subsection{Tahapan Penelitian}

Tahapan penelitian ini menggunakan susunan tahapan yang digunakan oleh Budi (2012), yaitu:

\subsubsection{Pembuatan gagasan/ide}

Ide penelitian terinspirasi dari latar belakang penulis sebagai pendidik matakuliah Akuntansi Keuangan dan Pajak Penghasilan. Uraian detail latar belakang munculnya ide penulisan ini telah dijabarkan pada Bagian 1 tentang Pendahuluan. Sebagai tenaga pendidik di bidang perpajakan, penulis merasa perlu untuk memberikan kontribusi bagi otoritas perpajakan yang memiliki kewenangan untuk membuat peraturan perpajakan.

\subsubsection{Tinjauan literatur}

Berdasarkan gagasan dan rumusan masalah yang sudah ada, proses penelitian dilanjutkan dengan tinjauan literatur. Rincian literatur yang menjadi rujukan dalam penelitian ini telah diuraikan dalam subbagian 3.2.

\subsubsection{Desain penelitian}

Dalam proses ini, perhatian pertama difokuskan pada pemahaman Kerangka Dasar Penyusunan Penyajian Laporan Keuangan (Penyesuaian 2014) dan PSAK 16 (Penyesuaian 2014) untuk mengetahui konsep penghasilan dan penilaian aset tetap menurut akuntansi. Tahap pertama diilustrasikan dalam Gambar 1 (lihat Lampiran).

Tahapan kedua, perhatian difokuskan pada pemahaman konsep penghasilan dan perlakuan penilaian aset tetap menurut peraturan perpajakan. Tahap kedua diilustrasikan dalam Gambar 2 (lihat Lampiran).

\subsubsection{Pengumpulan data}

Data berupa literatur PSAK, ketentuan perpajakan, buku teks, dan jurnal dikumpulkan melalui beberapa cara, yaitu:

a. meminjam buku PSAK dari perpustakaan;

b. mengunduh peraturan perpajakan dari taxbase; dan

c. mengunduh e-book buku teks atau jurnal yang terkait dengan tema penelitian.

\subsubsection{Analisis dan temuan}

Setelah diperoleh pemahaman pengakuan penghasilan dan kenaikan atau penurunan nilai aset tetap menurut akuntansi maupun peraturan perpajakan, langkah selanjutnya adalah mengidentifikasi:

a. apakah ada perbedaan perlakuan penilaian aset tetap menurut akuntansi dan peraturan perpajakan?

b. apakah ada perbedaan konsep penghasilan menurut akuntansi dan peraturan perpajakan?

c. apakah ada perbedaan perlakuan kenaikan atau penurunan nilai aset tetap menurut akuntansi dan peraturan perpajakan?

d. apakah pengenaan Pajak Penghasilan telah sesuai dengan konsep penghasilan menurut peraturan perpajakan?

Proses identifikasi dapat diilustrasikan dalam Gambar 3 (lihat Lampiran).

\section{PEMBAHASAN}

\subsection{Perlakuan Penilaian Aset Tetap Menurut PSAK dan Peraturan Perpajakan}

Sesuai PSAK 16 (Penyesuaian 2014), entitas dapat memilih model biaya atau model revaluasi untuk pengukuran aset tetap setelah pengakuan awal. Dalam model biaya, setelah pengakuan sebagai aset, aset tetap dicatat pada biaya perolehan dikurangi akumulasi penyusutan dan akumulasi rugi penurunan nilai. Dalam model revaluasi, setelah pengakuan sebagai aset, aset tetap yang nilai wajarnya dapat 
diukur secara andal dicatat pada jumlah revaluasian, yaitu nilai wajar pada tanggal revaluasi dikurangi akumulasi penyusutan dan akumulasi rugi penurunan nilai yang terjadi setelah tanggal revaluasi.

Ketika entitas memilih menggunakan model revaluasi, entitas akan membandingkan antara nilai tercatat aset tetap dengan nilai wajar aset tetap tersebut. Terdapat dua kemungkinan pada saat revaluasi, yaitu mendapatkan keuntungan atau kerugian (Weygandt et.al, 2015)

a. Keuntungan (gain)

Yaitu nilai tercatat lebih rendah dibandingkan nilai wajar. Jika jumlah tercatat aset meningkat akibat revaluasi maka kenaikan tersebut diakui dalam penghasilan komprehensif lain dan terakumulasi dalam ekuitas pada bagian surplus revaluasi.

Contoh 1:

PT ABC membeli Peralatan pada tanggal 1 Januari 2016 sebesar Rp300.000.000,00. Aset mempunyai umur ekonomis lima tahun dan tidak ada nilai residu. Penyusutan menggunakan metode garis lurus. PT ABC memilih model revaluasi untuk pengukuran aset tetap setelah pengakuan awal. Nilai terbawa Peralatan pada tanggal 31 Desember 2016 sebesar Rp240.000.000,00 (harga perolehan sebesar Rp300.000.000,00 dan akumulasi penyusutan sebesar Rp60.000.000,00) dan nilai wajarnya sebesar Rp280.000.000,00 maka jurnal yang dibuat pada tanggal 31 Desember 2016 sebagai berikut:

\begin{tabular}{|c|c|c|c|}
\hline 31 Des 2018 & $\begin{array}{c}\text { Akumulasi Penyusutan } \\
\text { Peralatan } \\
\text { Surplus Revaluasi }\end{array}$ & Rpe0.000.000,00 & $\begin{array}{l}\text { Rp20.000.000,00 } \\
\text { Rp } 40.000 .000,00\end{array}$ \\
\hline
\end{tabular}

Nilai selisih lebih revaluasi sebesar Rp40.000.000,00 dilaporkan sebagai Penghasilan Komprehensif Lain dalam Laporan Laba Rugi Komprehensif dan dilaporkan sebagai bagian Ekuitas dalam Laporan Posisi Keuangan. b. Kerugian (loss)

Yaitu nilai tercatat lebih tinggi dibandingkan nilai wajar. Jika jumlah tercatat aset turun akibat revaluasi maka penurunan tersebut diakui dalam laba rugi.

Contoh 2:

PT XYZ membeli Peralatan pada tanggal 1 Januari 2016 sebesar Rp300.000.000,00. Aset mempunyai umur ekonomis lima tahun dan tidak ada nilai residu. Penyusutan menggunakan metode garis lurus. PT XYZ memilih model revaluasi untuk pengukuran aset tetap setelah pengakuan awal. Nilai terbawa Peralatan pada tanggal 31 Desember 2016 sebesar Rp240.000.000,00 (harga perolehan sebesar Rp300.000.000,00 dan akumulasi penyusutan sebesar Rp60.000.000,00) dan nilai wajarnya sebesar Rp220.000.000,00 maka jurnal yang dibuat pada tanggal 31 Desember 2016 sebagai berikut:

\begin{tabular}{|c|l|r|r|}
\hline 31 Des 2018 & $\begin{array}{l}\text { Akumulasi Penyusutan } \\
\text { Rugi Penurunan Nilai } \\
\text { Peralatan }\end{array}$ & $\begin{array}{l}\text { Rp80.000.000,00 } \\
\text { Rp20.000.000,00 }\end{array}$ & Rp80.000.000,00 \\
\hline
\end{tabular}

Nilai selisih kurang revaluasi sebesar Rp20.000.000,00 dilaporkan sebagai kerugian dalam Laporan Laba Rugi.

Untuk tujuan perpajakan, pengukuran aset tetap setelah pengakuan awal yang diizinkan adalah model biaya. Entitas sebagai Wajib Pajak badan dalam negeri dan BUT dapat menggunakan model revaluasi untuk tujuan perpajakan dengan syarat entitas harus mengajukan permohonan kepada Dirjen Pajak.
Berbeda dengan perlakuan akuntansi di mana terdapat dua kemungkinan saat perusahaan melakukan revaluasi, yaitu terjadi kenaikan nilai aset tetap (selisih lebih revaluasi) atau penurunan nilai aset tetap, maka untuk tujuan perpajakan yang diperbolehkan adalah ketika terjadi kenaikan nilai aset tetap (selisih lebih revaluasi) sedangkan penurunan nilai aset tetap tidak diperbolehkan. Dalam hal terjadi selisih lebih revaluasi, entitas dikenai Pajak Penghasilan Final sebesar 10\% dari selisih lebih revaluasi. Selisih lebih revaluasi merupakan selisih lebih antara harga wajar/harga pasar aset tetap dengan nilai sisa buku secara fiskal. Dalam hal terjadi rugi penurunan nilai, kerugian tersebut tidak boleh dikurangkan dalam penghitungan Penghasilan Kena Pajak.

Contoh 3:

PT ZZZ membeli Peralatan pada tanggal 1 Januari 2016 sebesar Rp300.000.000,00. Aset mempunyai umur ekonomis lima tahun dan tidak ada nilai residu. Untuk kepentingan pajak, Peralatan masuk kelompok 1. PT ZZZ menggunakan metode garis lurus untuk melakukan penyusutan secara komersial maupun fiskal. Tarif penyusutan garis lurus secara fiskal sesuai Pasal 11 ayat (6) UU Pajak Penghasilan untuk aset tetap kelompok 1 adalah sebesar $25 \%$. PT ZZZ memilih model revaluasi untuk pengukuran aset tetap setelah pengakuan awal. Pada tanggal 31 Desember 2016, nilai wajar Peralatan sebesar Rp275.000.000,00, nilai sisa buku fiskal sebesar Rp225.000.000,00 (harga perolehan sebesar Rp300.000.000,00 dikurangi akumulasi penyusutan sebesar Rp75.000.000,00), dan nilai sisa buku komersial sebesar Rp240.000.000,00 (harga perolehan sebesar Rp300.000.000,00 dikurangi akumulasi penyusutan sebesar Rp60.000.000,00). Jika PT ZZZ mengajukan permohonan revaluasi aset tetap untuk tujuan perpajakan maka jurnal yang dibuat pada tanggal 31 Desember 2016 sebagai berikut:

\begin{tabular}{|c|c|c|c|}
\hline 31 Des 2018 & $\begin{array}{l}\text { Akumulasi Penyusutan Peralatan } \\
\text { Peralatan } \\
\text { Utang Pajak PenghasilaniKas } \\
\text { Selisih Lebih Penilaian Kembali } \\
\text { Aset Tetap Perusahaan } \\
\text { Tgl } 31 \text { Des } 2016\end{array}$ & $R, 80.000 .000,00$ & 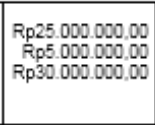 \\
\hline
\end{tabular}

Nilai selisih lebih revaluasi sebesar Rp30.000.000,00 dilaporkan sebagai bagian Ekuitas dalam Laporan Posisi Keuangan.

Contoh 4:

PT AAA membeli Peralatan pada tanggal 1 Januari 2016 sebesar Rp300.000.000,00. Aset mempunyai umur ekonomis lima tahun dan tidak ada nilai residu. Untuk kepentingan pajak, Peralatan masuk kelompok 1. PT AAA menggunakan metode garis lurus untuk melakukan penyusutan secara komersial maupun fiskal. Tarif penyusutan garis lurus secara fiskal sesuai Pasal 11 ayat (6) UU Pajak Penghasilan untuk aset tetap kelompok 1 adalah sebesar 25\%. PT AAA memilih model revaluasi untuk pengukuran aset tetap setelah pengakuan awal. Pada tanggal 31 Desember 2016, nilai wajar Peralatan sebesar Rp200.000.000,00, nilai sisa buku fiskal sebesar Rp225.000.000,00 (harga perolehan sebesar Rp300.000.000,00 dikurangi akumulasi penyusutan sebesar Rp75.000.000,00), dan nilai sisa buku komersial sebesar Rp240.000.000,00 (harga perolehan sebesar Rp300.000.000,00 dikurangi akumulasi penyusutan sebesar Rp60.000.000,00). PT 
AAA tidak diperkenankan mengajukan permohonan revaluasi aset tetap untuk tujuan perpajakan disebabkan terjadi penurunan nilai aset tetap secara fiskal sebesar Rp25.000.000,00 (harga pasar aset sebesar Rp200.000.000,00 dikurangi nilai sisa buku fiskal sebesar Rp225.000.000,00). Demikian juga, penurunan nilai ini tidak boleh dikurangkan dalam penghitungan Penghasilan Kena Pajak.

\subsection{Analisis Selisih Lebih Revaluasi Aset Tetap Berdasarkan Konsep Penghasilan Menurut PSAK dan Peraturan Perpajakan}

Konsep penghasilan menurut akuntansi diatur dalam Kerangka Dasar Penyusunan dan Penyajian Laporan Keuangan (Penyesuaian 2014). Menurut akuntansi, penghasilan (income) meliputi baik pendapatan (revenues) maupun keuntungan (gains). Pendapatan timbul dalam pelaksanaan aktivitas perusahaan yang biasa dan dikenal dengan sebutan yang berbeda seperti penjualan, penghasilan jasa (fees), bunga, dividen, royalti, dan sewa. Keuntungan mencerminkan pos lainnya yang memenuhi definisi penghasilan dan mungkin timbul atau mungkin tidak timbul dalam pelaksanaan aktivitas entitas yang biasa. Keuntungan meliputi, sebagai contoh pos yang timbul dalam pengalihan aset tidak lancar. Definisi penghasilan juga mencakup keuntungan yang belum direalisasi, sebagai contoh yang timbul dari revaluasi sekuritas yang dapat dipasarkan (marketable) dan dari kenaikan jumlah aset jangka panjang. Lebih lanjut, Kerangka Dasar Penyusunan dan Penyajian Laporan Keuangan (Penyesuaian 2014) memberikan pedoman kapan entitas mengakui pengakuan. Menurut akuntansi, penghasilan diakui dalam laporan laba rugi ketika kenaikan manfaat ekonomik di masa depan yang berkaitan dengan kenaikan aset atau penurunan liabilitas telah terjadi dan dapat diukur dengan andal. Ini berarti pengakuan penghasilan terjadi bersamaan dengan pengakuan kenaikan aset atau penurunan liabilitas (sebagai contoh kenaikan bersih aset yang timbul dari penjualan barang atau jasa atau penurunan liabilitas yang timbul dari pembebasan pinjaman yang masih harus dibayar).

Berdasarkan Kerangka Dasar Penyusunan dan Penyajian Laporan Keuangan (Penyesuaian 2014) jelas disebutkan bahwa penghasilan juga mencakup keuntungan yang belum direalisasi. Pada saat entitas melakukan revaluasi aset tetap, terdapat dua kemungkinan yang terjadi, yaitu keuntungan (gain) atau kerugian (loss). Keuntungan terjadi apabila terdapat selisih lebih revaluasi, yaitu harga pasar aset tetap lebih tinggi dibandingkan nilai terbawa. Sedangkan kerugian terjadi apabila harga pasar aset tetap lebih rendah dibandingkan nilai terbawa. Pada contoh 1, entitas mendapatkan keuntungan sebesar Rp40.000.000,00, yaitu harga pasar sebesar Rp280.000.000,00 dikurangi nilai terbawa sebesar Rp240.000.000,00. Keuntungan ini bagi PT $A B C$ merupakan keuntungan yang belum direalisasi tetapi berdasarkan konsep penghasilan menurut akuntansi sudah dapat diakui sebagai penghasilan sepanjang memenuhi kriteria pengakuan penghasilan. Pedoman pengakuan penghasilan menurut akuntansi yaitu penghasilan diakui dalam laporan laba rugi ketika kenaikan manfaat ekonomik di masa depan yang berkaitan dengan kenaikan aset atau penurunan liabilitas telah terjadi dan dapat diukur dengan andal. Dalam contoh 1, telah terjadi kenaikan aset Peralatan yang nilainya dapat diukur dengan andal yaitu berdasarkan harga pasarnya. Dengan demikian, PT ABC mengakui keuntungan yang belum direalisasi dari selisih lebih revaluasi aset tetap sebagai penghasilan bersamaan dengan pengakuan kenaikan aset Peralatan.

Konsep penghasilan menurut UU Pajak Penghasilan adalah "setiap tambahan kemampuan ekonomis yang diterima atau diperoleh Wajib Pajak, baik yang berasal dari Indonesia maupun dari luar Indonesia, yang dapat dipakai untuk konsumsi atau untuk menambah kekayaan Wajib Pajak yang bersangkutan, dengan nama dan dalam bentuk apa pun...". Menurut Markus dan Yujana (2004), penggunaan frasa "yang diterima atau diperoleh Wajib Pajak" menunjukkan bahwa untuk dapat diakui sebagai penghasilan, setiap tambahan kemampuan ekonomis tersebut harus sudah direalisasikan oleh Wajib Pajak. Hal ini berarti bahwa setiap tambahan kemampuan ekonomis yang belum direalisasikan belum dianggap sebagai penghasilan. Mansury dalam Markus dan Yujana (2004) menyatakan bahwa UU Pajak Penghasilan menggunakan realization criterion yang dikenal dalam akuntansi sehingga tambahan kemampuan ekonomis itu baru dapat dikenai pajak apabila diterima secara tunai (basis kas) atau apabila hak untuk meminta pemenuhan pembayaran telah dapat dicatat dalam akuntansi Wajib Pajak (basis akrual). Lebih lanjut Markus dan Yujana (2004) menyatakan kriteria konsep realisasi menurut UU Pajak Penghasilan yaitu:

a. Realisasi merupakan faktor determinan dalam penghasilan. Artinya, begitu terjadi realisasi maka timbul penghasilan.

b. Realisasi diartikan secara sempit sebagai perubahan hak atau kepemilikan atau penguasaan atas aset dan/atau kewajiban, baik aset atau kewajiban yang sama maupun aset atau kewajiban yang telah berubah bentuk atau substansi.

c. Perubahan bentuk menuntut adanya transaksi eksternal. Transaksi internal tidak akan menimbulkan hak atau kewajiban baru bagi perusahaan.

d. Pengertian transaksi eksternal atau transaksi dengan pihak luar entitas menurut UU Pajak Penghasilan diartikan sebagai transaksi dengan pihak Subjek Pajak lain. Dalam akuntansi, pihak luar entitas bisa pihak Subjek Pajak yang berbeda atau pihak Subjek Pajak yang sama.

e. UU Pajak Penghasilan tidak menentukan bahwa perubahan hak atas aset atau kewajiban baru dapat dicatat dalam pembukuan jika aset atau kewajiban itu sudah bisa diukur dan sudah dapat diuangkan.

Pada contoh 3, entitas sebagai Wajib Pajak mendapatkan keuntungan berupa selisih lebih revaluasi aset tetap untuk tujuan perpajakan sebelum dikenai pajak sebesar Rp50.000.000,00, yaitu harga 
pasar aset tetap sebesar Rp275.000.000,00 dikurangi nilai sisa buku fiskal sebesar Rp225.000.000,00. Berdasarkan konsep penghasilan menurut UU Pajak Penghasilan, keuntungan selisih lebih revaluasi aset tetap untuk tujuan perpajakan ini adalah bukan penghasilan karena tidak memenuhi kriteria sudah direalisasi oleh entitas sebagai Wajib Pajak. Pertama, saat PT ZZZ melakukan revaluasi aset tetap tidak ada perubahan hak atau kepemilikan atau penguasaan atas aset tetap tersebut. Aset tetap yang direvaluasi tetap dikuasai atau dimiliki oleh PT ZZZ. Aset tetap yang direvaluasi tidak dialihkan kepada pihak lain. Kedua, tidak ada transaksi eksternal terkait revaluasi aset tetap. Revaluasi aset tetap merupakan transaksi internal PT ZZZ sebagai Wajib Pajak dan tidak melibatkan entitas lain sebagai Wajib Pajak. Oleh karena itu, apabila timbul selisih lebih akibat revaluasi aset tetap tersebut, selisih lebih tersebut menurut prinsip pajak belum diakui sebagai penghasilan karena belum direalisasi.

\subsection{Analisis Pengenaan Pajak Penghasilan atas Selisih Lebih Revaluasi Aset Tetap Berdasarkan Konsep Penghasilan \\ Terkait dengan kelaziman pengenaan Pajak} Penghasilan atas selisih lebih revaluasi aset tetap, mau tidak mau kita akan kembali ke prinsip dan konsep pengenaan Pajak Penghasilan yang lazim diterima dan diterapkan. Sejauh ini, konsep penghasilan serta pengakuannya untuk kepentingan perpajakan sendiri menuai banyak perdebatan. Organisasi untuk Kerja Sama dan Pembangunan Ekonomi (OECD Organisation for Economic Co-operation and Development), misalnya, dalam literatur yang diterbitkan tahun 2014, menyatakan bahwa pada dasarnya pajak penghasilan dikenakan atas realisasi penghasilan bersih oleh Wajib Pajak dalam satu periode penghasilan. Pendapat lain disampaikan oleh Simon (1938) yang lebih menekankan konsep penghasilan sebagai objek pajak haruslah bisa dikuantifikasikan, jadi harus dapat diukur dan mengandung konsep perolehan (acquisitive concept). Acquisitive concept memandang bahwa konsep penghasilan diejawantahkan dalam bentuk kemampuan untuk menguasai barang dan jasa yang dapat dipergunakan untuk memenuhi kebutuhan. Simon menekankan pada pengukuran berkenaan dengan apa yang diperoleh itu. Sementara Kwall (2010) membuat argumentasi mengenai perlakuan perpajakan yang berlaku di Amerika Serikat yang menekankan prinsip realisasi dalam pengenaan pajaknya. Kwall berpendapat bahwa pajak penghasilan sudah seharusnya dikenakan pada saat terjadi selisih lebih nilai aset (asset appreciation) dengan mempertimbangkan kenaikan nilai ekuitas serta masalah efisiensi pengenaan pajak, tanpa harus menunggu sampai dengan terjadi realisasi penjualan. Di Jepang, keuntungan karena revaluasi aset tidak dikenai pajak kecuali untuk kasus khusus tertentu seperti revaluasi yang dilakukan berdasarkan undangundang reorganisasi korporasi (Corporation Reorganization Law). Demikian juga, kerugian penurunan aset tetap, selain kerusakan karena bencana alam atau keusangan, tidak diperkenankan untuk tujuan pajak (KPMG Tax Corporation, 2016).

Di Indonesia, objek Pajak Penghasilan menurut Pasal 4 ayat (1) UU Pajak Penghasilan adalah penghasilan, yaitu setiap tambahan kemampuan ekonomis yang diterima atau diperoleh Wajib Pajak, baik yang berasal dari Indonesia maupun dari luar Indonesia, yang dapat dipakai untuk konsumsi atau untuk menambah kekayaan Wajib Pajak yang bersangkutan, dengan nama dan dalam bentuk apa pun. Salah satu jenis penghasilan menurut Pasal 4 ayat (1) huruf m UU Pajak Penghasilan adalah selisih lebih revaluasi aset tetap. Lebih lanjut, pengenaan Pajak Penghasilan atas selisih lebih revaluasi aset tetap diatur dalam Pasal 19 UU Pajak Penghasilan dan Peraturan Menteri Keuangan Nomor 79/PMK.03/2008. Menurut ketentuan dalam peraturan ini, atas selisih lebih revaluasi aset tetap untuk tujuan perpajakan dikenai Pajak Penghasilan yang bersifat final sebesar $10 \%$. Khusus untuk revaluasi aset tetap untuk tujuan perpajakan yang diajukan selama tahun 2015-2016 terjadi penurunan tarif menjadi sebesar 3\% (untuk pengajuan sampai dengan 31 Desember 2015), 4\% (untuk pengajuan 1 Januari sampai dengan 30 Juni 2016), dan 6\% (untuk pengajuan 1 Juli sampai dengan 31 Desember 2016) sesuai Peraturan Menteri Keuangan Nomor 191/PMK.010/2015 jo Peraturan Menteri Keuangan Nomor 233/PMK.03/2015 jo Peraturan Menteri Keuangan Nomor 29/PMK.03/2016. Berdasarkan peraturan perpajakan yang berlaku di Indonesia, tambahan kemampuan ekonomis dalam bentuk selisih lebih revaluasi aset tetap dikenai pajak pada saat terjadi revaluasi. Ini berarti bahwa selisih lebih revaluasi aset tetap dikenai pajak pada saat penghasilan belum direalisasi. Sesuai dengan prinsip pengakuan penghasilan sebagai objek pajak seharusnya pada saat terjadi revaluasi belum dikenai Pajak Penghasilan karena belum ada realisasi penghasilan. Tetapi, jika selisih lebih akibat revaluasi aset tetap - yang dalam Laporan Posisi Keuangan dicatat dalam kelompok ekuitas berupa Surplus Revaluasi - dialihkan atau dicatat sebagai saham bonus atau penambahan saham tanpa setoran maka pada waktu itulah terjadi realisasi karena pada saat itu terjadi transaksi ekternal antara perusahaan dengan pemegang sahamnya (Markus dan Yujana, 2004). Seharusnya, pada saat pengalihan selisih lebih revaluasi aset tetap menjadi saham bonus kepada pemegang saham inilah dikenai Pajak Penghasilan. Namun, peraturan perpajakan yang berlaku di Indonesia mengatur sebaliknya. Pasal 2 huruf b Peraturan Pemerintah Nomor 94 Tahun 2010 mengatur bahwa objek pajak berupa dividen sebagaimana dimaksud dalam Pasal 4 ayat (1) huruf $g$ UU Pajak Penghasilan tidak termasuk pemberian saham bonus yang dilakukan tanpa penyetoran yang berasal dari kapitalisasi selisih lebih penilaian kembali aset tetap sebagaimana dimaksud dalam Pasal 19 ayat (1) UU Pajak Penghasilan. Demikian juga Pasal 9 ayat (2) Peraturan Menteri Keuangan Nomor 79/PMK.03/2008 mengatur bahwa pemberian saham bonus atau pencatatan tambahan nilai nominal saham 
tanpa penyetoran yang berasal dari kapitalisasi selisih lebih penilaian kembali aset tetap perusahaan, sampai dengan sebesar selisih lebih penilaian kembali secara fiskal bukan merupakan objek pajak berdasarkan Pasal 4 ayat (1) huruf g UU Pajak Penghasilan. Berdasarkan peraturan perpajakan yang berlaku dapat ditarik kesimpulan bahwa selisih lebih revaluasi aset tetap dikenakan pada saat penghasilan belum direalisasi, yaitu pada saat terjadi revaluasi, dengan pembebanan pembayaran pajak ada pada perusahaan. Pada saat terjadi realisasi penghasilan, yaitu pemberian saham bonus yang berasal dari kapitalisasi selisih lebih revaluasi aset tetap kepada pemegang saham, tidak dikenai pajak. Artinya, pemegang saham tidak dibebani pembayaran pajak atas selisih lebih revaluasi aset tetap.

Aset tetap yang telah mendapatkan persetujuan revaluasi aset tetap tidak boleh dialihkan sebelum berakhirnya masa manfaat yang baru (untuk aset tetap kelompok 1 dan kelompok 2) atau sebelum lewat jangka waktu 10 tahun (untuk aset tetap kelompok 3, kelompok 4, bangunan, dan tanah). Jika entitas sebagai Wajib Pajak mengalihkannya sebelum lewat jangka tersebut maka atas selisih lebih revaluasi aset tetap semula dikenai tambahan Pajak Penghasilan Final sebesar tarif tertinggi Pajak Penghasilan Wajib Pajak badan dalam negeri yang berlaku pada saat revaluasi dikurangi $10 \%$. Jika pengalihan aset tetap melewati jangka waktu yang ditetapkan maka akan berlaku ketentuan umum. Untuk aset tetap selain bangunan dan tanah, keuntungan pengalihan merupakan objek pajak sesuai Pasal 4 ayat (1) huruf d UU Pajak Penghasilan yang dikenai tarif umum Pajak Penghasilan Pasal 17. Sebaliknya, kerugian pengalihan merupakan beban yang dapat dikurangkan dari penghasilan bruto untuk menghitung besarnya penghasilan kena pajak sesuai Pasal 6 ayat (1) huruf d UU Pajak Penghasilan. Khusus untuk pengalihan aset tetap berupa bangunan dan tanah dikenai pajak penghasilan atas pengalihan tanah dan/atau bangunan sebagaimana diatur dalam Pasal 4 ayat (2) huruf d UU Pajak Penghasilan jo Peraturan Pemerintah Nomor 34 Tahun 2016. Saat entitas sebagai Wajib Pajak mengalihkan aset tetap yang direvaluasi, pada saat itulah terjadi realisasi penghasilan karena ada transaksi eksternal dengan entitas lain sebagai Wajib Pajak. Pengenaan pajak pada saat pengalihan aset tetap yang telah direvaluasi ini telah sesuai dengan konsep penghasilan sebagai objek pajak.

Berdasarkan pembahasan di atas, perbandingan pengenaan pajak atas selisih lebih revaluasi aset tetap menurut peraturan perpajakan yang berlaku dengan menurut konsep penghasilan dapat diilustrasikan dalam Gambar 4 dan Gambar 5 (lihat Lampiran).

\subsection{Pengenaan Pajak Penghasilan atas Selisih Lebih Revaluasi Aset Tetap Berdasarkan Perspektif Konvergensi IFRS}

Pelaporan nilai aset tetap berdasarkan fair value merupakan suatu keniscayaan yang dilakukan oleh setiap entitas sejak dicanangkannya komitmen konvergensi IFRS. Sebaliknya, pengenaan pajak penghasilan atas selisih lebih revaluasi aset tetap mempunyai implikasi penyematan semangat yang berseberangan dengan komitmen untuk meningkatkan kualitas pelaporan keuangan entitas sebagai Wajib Pajak. Penelitian Purwanti et.al (2017) memberikan bukti bahwa penurunan tarif Pajak Penghasilan atas selisih lebih revaluasi aset tetap pada tahun 2015-2016 berpengaruh terhadap peningkatan jumlah entitas yang melaporkan penilaian asetnya dengan model revaluasi. Jika selisih lebih revaluasi aset tetap untuk tujuan perpajakan tidak dikenai Pajak Penghasilan diharapkan akan mendorong entitas melaporkan aset tetapnya berdasarkan model revaluasi.

Entitas sebagai Wajib Pajak dapat saja melaporkan nilai aset tetapnya berdasarkan fair value untuk laporan keuangan komersial dan melaporkan nilai aset tetapnya berdasarkan historical cost untuk tujuan fiskal. Namun, penyusunan dua laporan yang berbeda tentunya akan menambah beban bagi entitas sebagai Wajib Pajak.

Penyusunan dua laporan yang berbeda untuk tujuan komersial dan fiskal bukan tidak menimbulkan masalah. Entitas sebagai Wajib Pajak harus melampirkan laporan keuangan komersial dalam SPT Tahunan. Dalam hal laporan keuangan telah diaudit Akuntan Publik maka laporan keuangan auditan tersebut harus dilampirkan dalam SPT Tahunan. Jika tidak dilampirkan, SPT Tahunan dianggap tidak disampaikan sesuai Pasal 4 ayat (4b) UU KUP. Jadi, yang disampaikan ke Kantor Pelayanan Pajak adalah laporan keuangan komersial yang memuat revaluasi aset tetap. Ketika entitas menerapkan model revaluasi tetapi tidak mengajukan permohonan kepada Dirjen Pajak pertanyaan yang muncul adalah apakah selisih lebih revaluasi aset tetap tersebut dikenai Pajak Penghasilan Final. Hasil penelitian Budi (2012) menyatakan bahwa terdapat perbedaan pendapat mengenai hal tersebut. Di satu sisi, penambahan nilai aset dapat dikategorikan sebagai tambahan kemampuan ekonomis yang merupakan objek pajak penghasilan sesuai Pasal 4 UU Pajak Penghasilan. Akan tetapi, di sisi lain, Pasal 19 UU Pajak Penghasilan juga mengamanatkan ada Peraturan Menteri Keuangan, yaitu Peraturan Menteri Keuangan Nomor 79/PMK.03/2008 terkait dengan penilaian kembali aset tetap untuk tujuan perpajakan. Peraturan Menteri Keuangan Nomor 79/PMK.03/2008 mengatur bahwa penilaian kembali aset tetap untuk tujuan perpajakan harus mendapat persetujuan Dirjen Pajak sehingga selisih lebih revaluasi karena penerapan model revaluasi tidak otomatis mengakibatkan adanya tambahan kemampuan ekonomis sehingga muncul objek pajak penghasilan atas selisih lebih tersebut. Namun demikian, sangat mungkin terjadi bahwa petugas pajak dalam praktik di lapangan lebih cenderung mengacu pada Pasal 4 UU Pajak Penghasilan. Akibatnya, entitas sebagai Wajib Pajak badan dapat dirugikan karena penerapan model revaluasi tersebut. Terlebih lagi, ketentuan perpajakan tidak memperkenankan adanya penurunan nilai aset. 


\section{PENUTUP}

\subsection{Simpulan}

a. Terdapat perbedaan perlakuan penilaian aset tetap menurut akuntansi (PSAK 16) dengan menurut peraturan perpajakan. Akuntansi memperkenankan bagi entitas untuk memilih model biaya atau model revaluasi, sedangkan peraturan perpajakan hanya memperkenankan penggunaan model biaya. Penggunaan model revaluasi diperkenankan dengan syarat entitas sebagai Wajib Pajak harus mengajukan permohonan kepada Dirjen Pajak, selisih lebih revaluasi dikenai pajak, dan tidak diperkenankan adanya penurunan nilai aset tetap.

b. Terdapat perbedaan pengakuan penghasilan menurut akuntansi dan konsep penghasilan menurut peraturan perpajakan. Penghasilan dalam akuntansi mencakup pendapatan dan keuntungan baik yang sudah direalisasi maupun yang belum direalisasi. Sedangkan menurut konsep penghasilan sesuai peraturan perpajakan, penghasilan diakui ketika sudah direalisasi, yaitu ada transaksi eksternal.

c. Pengenaan Pajak Penghasilan atas selisih lebih revaluasi aset tetap berdasarkan konsep penghasilan adalah kurang tepat karena tambahan kemampuan ekonomis berupa kenaikan nilai aset tetap tersebut belum direalisasi oleh entitas sebagai Wajib Pajak karena tidak terjadi transaksi eksternal. Sebaliknya, pada saat terjadi realisasi penghasilan, yaitu pemberian saham bonus yang berasal dari kapitalisasi selisih lebih revaluasi aset tetap kepada pemegang saham (terjadi transaksi eksternal), tidak dikenai pajak. Sedangkan pengenaan pajak pada saat pengalihan aset tetap yang telah direvaluasi telah sesuai dengan konsep penghasilan.

d. Pengenaan pajak penghasilan atas selisih lebih revaluasi aset tetap berdasarkan perspektif konvergensi IFRS dapat berimplikasi penyematan semangat yang berseberangan dengan komitmen untuk meningkatkan kualitas pelaporan keuangan entitas sebagai Wajib Pajak. Dengan kata lain, DJP belum mengakomodasi entitas sebagai Wajib Pajak untuk melaporkan aset tetapnya dalam laporan keuangan untuk kepentingan perpajakan sesuai prinsip konvergensi IFRS. Dalam hal entitas sebagai Wajib Pajak menerapkan konvergensi IFRS tersebut maka sesuai ketentuan akan mempunyai implikasi terhadap dikenakannya pajak penghasilan atas selisih lebih nilai aset tetap tersebut (harga pasar dikurangi nilai sisa buku fiskal).

\subsection{Saran}

a. Selaras dengan komitmen Indonesia untuk melakukan konvergensi IFRS maka otoritas pajak, dalam hal ini adalah Direktorat Jenderal Pajak, perlu untuk menyeimbangkan dan menyelaraskan setiap peraturannya dengan spirit perkembangan dunia usaha sehingga tidak terjadi ketimpangan yang terlalu lebar antara peraturan pajak dengan praktik bisnis yang lazim. Pengenaan Pajak Penghasilan atas selisih lebih revaluasi aset tetap sebagai penerapan model revaluasi dalam pelaporan aset tetap entitas sebagai Wajib Pajak berseberangan dengan komitmen konvergensi IFRS.

b. Direktorat Jenderal Pajak perlu mengkaji ulang ketentuan tentang pengenaan pajak penghasilan atas selisih lebih revaluasi aset tetap untuk tujuan perpajakan dengan pertimbangan bahwa tambahan kemampuan ekonomis berupa selisih lebih revaluasi aset tetap tersebut belum direalisasi oleh entitas sebagai Wajib Pajak. Pengenaan pajak akan lebih tepat dikenakan pada saat realisasi, yaitu pada saat selisih lebih revaluasi aset tetap dialihkan kepada pemegang saham dalam bentuk pemberian saham bonus.

\section{KETERBATASAN}

Penelitian ini hanya didasarkan pada studi literatur. Penelitian selanjutnya dapat menggunakan data kuantitatif perusahaan yang terdaftar di Bursa Efek Indonesia dan data Wajib Pajak dari Kantor Pelayanan Pajak yang menggunakan model revaluasi untuk tujuan komersial dan tujuan fiskal. Rentang waktu penelitian mencakup periode adanya perubahan tarif Pajak Penghasilan atas selisih lebih revaluasi aset tetap untuk tujuan perpajakan.

\section{DAFTAR PUSTAKA}

\section{Peraturan}

Undang-Undang Nomor 28 Tahun 2007 tentang Perubahan Ketiga Atas Undang-Undang Nomor 6 Tahun 1983 tentang Ketentuan Umum dan Tata Cara Perpajakan.

Undang-Undang Nomor 36 Tahun 2008 tentang Perubahan Keempat atas Undang-Undang Nomor 7 Tahun 1983 tentang Pajak Penghasilan.

Peraturan Pemerintah Nomor 34 Tahun 2016 tentang Pajak Penghasilan Atas Penghasilan dari Pengalihan Hak Atas Tanah dan/atau Bangunan, dan Perjanjian Pengikatan Jual Beli Atas Tanah dan/atau Bangunan Beserta Perubahannya.

Peraturan Menteri Keuangan Nomor 79/PMK.03/2008 tentang Penilaian Kembali Aktiva Tetap Perusahaan untuk Tujuan Perpajakan.

Peraturan Menteri Keuangan Nomor 191/PMK.010/2015 tentang Penilaian Kembali Aktiva Tetap untuk Tujuan Perpajakan Bagi Permohonan yang Diajukan pada Tahun 2015 dan Tahun 2016.

\section{Buku}

Budi, Prianto. 2012. Konvergensi IFRS dan Pengaruhnya Terhadap Perpajakan. Edisi Pertama. Jakarta, Indonesia: PT Pratama Indomitra Konsultan.

Cooper, D.R., dan Schindler, P.S. 2008. Business Research Method. 10 ${ }^{\text {th }}$ Edition. International Edition. New York: McGraw Hill Companies Inc. 
Ikatan Akuntan Indonesia. 2014. Kerangka Dasar Penyusunan dan Penyajian Laporan Keuangan (Penyesuaian 2014). Jakarta, Indonesia: Ikatan Akuntan Indonesia.

Ikatan Akuntan Indonesia. 2014. PSAK No. 1 (Penyesuaian 2014) Penyajian Laporan Keuangan. Jakarta, Indonesia: Ikatan Akuntan Indonesia.

Ikatan Akuntan Indonesia. 2014. PSAK No. 16 (Penyesuaian 2014) Aset Tetap. Jakarta, Indonesia: Ikatan Akuntan Indonesia.

KPMG Tax Corporation. 2015. Taxation in Japan 2016. Osaka.

https://assets.kpmg.com/content/dam/kpmg/j p/pdf/jp-en-taxation-in-japan-201612.pdf. Accessed October 10, 2017.

Kratzke, William. 2016. Basic Income Tax 2016-2017. Fourth Edition.

https://www.cali.org/sites/default/files/July2 92016_FINAL_4thEdition_KratzkeNOcover_Lu lu.pdf. Accessed November 13, 2017.

Markus, Muda., dan Lalu Hendry Yujana. 2004. Pajak Penghasilan. Edisi Revisi. Jakarta, Indonesia: PT Gramedia Pustaka Utama.

Martani, Dwi., Sylvia Veronica, Ratna Wardhani, Aria Farahmita, dan Edward Tanujaya. 2014. Akuntansi Keuangan Menengah. Buku 1. Jakarta, Indonesia: Salemba Empat.

Weygandt, Jerry., Paul Kimmel, and Don Kieso. 2015. Financial Accounting. $3 r^{d}$ Edition. IFRS Edition. USA: John Wiley \& Sons Inc.

\section{Jurnal dan Makalah}

Basu, Sudipta. 2009. "Conservatism Research: Historical Development and Future Prospects." China Journal Of Accounting Research. Vol. 2 (1). https://www.cb.cityu.edu.hk /research /cjar/doc/200906/01-Basu.pdf. Accessed October 10, 2017.

Juanda, Ahmad. 2012. “Kandungan Prinsip Konservatisme dalam Standar Akuntansi Keuangan Berbasis IFRS (International Financial Reporting Standard)." Jurnal Humanity. Volume 7 Nomor 2: 24-34.

Kwall, Jeffrey L. 2010. "When Should Asset Appreciation Be Taxed?: The Case for a Disposition Standard of Realization". Indiana Law Journal. Vol. 86:77-117. http://ilj.law.indiana.edu/articles/86/86_1_Kw all.pdf. Accessed October 10, 2017.

OECD. 2014. Fundamental Principles of Taxation. http://www.oecdilibrary.org/docserver/download/2314251ec00 5.pdf?expires $=1459787159 \&$ id $=i d \&$ accname $=g$ uest \&checksum=B6C8F5E6DB71F9F34B6E5000 B4CD36F5. Accessed October 10, 2017.
Purwanti, Dyah., lin Indrawati, and Benny Setiawan. 2017. "Revaluation Model, Tax Incentives, Debt Contract Motivation and Corporate Governance: Evidence in Indonesia." Paper presented at International Accounting Conference, Universitas Indonesia, Yogyakarta.

Saputra, Bobby Wiryawan., dan Agus Hermawan. 2012. "Perkembangan International Financial Reporting Standard (IFRS) dan Penerapannya di Indonesia." Accessed Oktober 10, 2017. https://www.researchgate.net/publication/266 105718.

Simons, H. C. 1938. Personal Income Taxation: The Definition of Income as a Problem of Fiscal Policy. Chicago: University of Chicago Press. 


\section{LAMPIRAN TABEL}

Tabel 1

Ringkasan Perbedaan Perlakuan Akuntansi dan Pajak untuk Aset Tetap

\begin{tabular}{|c|c|c|c|}
\hline No & Perihal & Akuntansi & Perpajakan \\
\hline 1. & Pengakuan & $\begin{array}{l}\text { Aset tetap diakui jika ada manfaat } \\
\text { ekonomis masa depan dan biaya } \\
\text { perolehan tersebut dapat diukur secara } \\
\text { andal }\end{array}$ & $\begin{array}{l}\text { Aset tetap diakui jika biaya perolehan } \\
\text { tersebut dapat diukur secara andal dan } \\
\text { jenis aset tetap tersebut tercakup di dalam } \\
\text { kelompok harta berwujud sesuai } \\
\text { PerMenkeu No 96/PMK.03/2009 }\end{array}$ \\
\hline 2. & Pengukuran & $\begin{array}{l}\text { Saat pengakuan awal, aset dicatat } \\
\text { berdasarkan biaya perolehan. } \\
\text { Pengukuran setelah pengakuan awal } \\
\text { dilakukan dengan model biaya atau } \\
\text { model revaluasi. } \\
\text { Dalam model revaluasi, nilai tercatat aset } \\
\text { disesuaikan dengan harga pasar sehingga } \\
\text { bisa mengalami peningkatan atau pun } \\
\text { penurunan. }\end{array}$ & $\begin{array}{l}\text { Saat pengakuan awal, aset diakui } \\
\text { berdasarkan biaya perolehan. } \\
\text { Pengukuran setelah pengakuan awal } \\
\text { dilakukan dengan model biaya. } \\
\text { Pengukuran setelah pengakuan awal bisa } \\
\text { dilakukan dengan model revaluasi } \\
\text { sepanjang diajukan permohonan kepada } \\
\text { Dirjen Pajak dan Dirjen Pajak berwenang } \\
\text { menerbitkan surat keputusan. }\end{array}$ \\
\hline 3. & Penyusutan & $\begin{array}{l}\text { Metode penyusutan tidak diatur secara } \\
\text { spesifik. } \\
\text { Masa manfaat ditentukan oleh entitas } \\
\text { dan perubahan masa manfaat diizinkan. } \\
\text { Nilai residu diperbolehkan. }\end{array}$ & $\begin{array}{l}\text { Metode penyusutan diatur secara spesifik } \\
\text { di dalam Pasal } 11 \text { UU Pajak Penghasilan. } \\
\text { Penyusutan yang diakui secara fiskal hanya } \\
\text { atas aset yang digunakan dalam operasi } \\
\text { perusahaan dalam hal mendapatkan, } \\
\text { menagih, dan memelihara penghasilan. } \\
\text { Masa manfaat diatur secara spesifik dalam } \\
\text { Pasal } 11 \text { UU Pajak Penghasilan. } \\
\text { Pada akhir masa manfaat tidak } \\
\text { diperkenankan adanya nilai residu. }\end{array}$ \\
\hline 4. & Penurunan nilai & Penurunan nilai aset diperbolehkan. & Penurunan nilai aset tidak diperkenankan. \\
\hline
\end{tabular}

Sumber: PSAK 16: Aset Tetap dan Pasal 11 UU Pajak Penghasilan

Tabel 2

Ringkasan Ketentuan Peraturan Menteri Keuangan Nomor 79/PMK.03/2008

\begin{tabular}{|l|l|l|l|}
\hline No & \multicolumn{1}{|c|}{ Perihal } & \multicolumn{1}{c|}{ Uraian } \\
\hline 1. & $\begin{array}{l}\text { Wajib Pajak } \\
\text { yang dapat } \\
\text { melakukan } \\
\text { revaluasi }\end{array}$ & $\begin{array}{l}\text { Wajib Pajak badan dalam negeri dan bentuk usaha tetap (BUT), tidak termasuk } \\
\text { perusahaan yang memperoleh izin menyelenggarakan pembukuan dalam bahasa } \\
\text { Inggris dan mata uang Dollar Amerika Serikat }\end{array}$ \\
\hline 2. & $\begin{array}{l}\text { Aset tetap yang } \\
\text { dapat dilakukan } \\
\text { revaluasi }\end{array}$ & $\begin{array}{l}\text { a. seluruh aset tetap berwujud, termasuk tanah yang berstatus hak milik atau hak } \\
\text { guna bangunan; atau } \\
\text { seluruh aset tetap berwujud tidak termasuk tanah } \\
\text { yang terletak atau berada di Indonesia, dimiliki, dan dipergunakan untuk mendapatkan, } \\
\text { menagih, dan memelihara penghasilan yang merupakan Objek Pajak. }\end{array}$ \\
\hline 3. & $\begin{array}{l}\text { Pengenaan } \\
\text { pajak }\end{array}$ & $\begin{array}{l}\text { Atas selisih lebih revaluasi aset tetap perusahaan di atas nilai sisa buku fiskal semula } \\
\text { dikenakan Pajak Penghasilan yang bersifat final sebesar 10\% (sepuluh persen). }\end{array}$ \\
\hline 4. & $\begin{array}{l}\text { Penyusutan } \\
\text { pasca revaluasi }\end{array}$ & $\begin{array}{l}\text { Dasar penyusutan fiskal adalah nilai pada saat penilaian kembali. } \\
\text { Masa manfaat disesuaikan kembali menjadi masa manfaat penuh. } \\
\text { Perhitungan penyusutan dimulai sejak bulan dilakukannya penilaian kembali aset tetap } \\
\text { perusahaan. }\end{array}$ \\
\hline 5. & $\begin{array}{l}\text { Penyajian dalam } \\
\text { laporan } \\
\text { keuangan } \\
\text { komersial }\end{array}$ & $\begin{array}{l}\text { Selisih lebih penilaian kembali di atas nilai sisa buku komersial semula setelah dikurangi } \\
\text { dengan Pajak Penghasilan revaluasi harus dibukukan dalam neraca komersial pada } \\
\text { perkiraan modal dengan nama "Selisih Lebih Penilaian Kembali Aset } \\
\text { Perusahaan Tanggal ......................" Tetap }\end{array}$ \\
\hline
\end{tabular}




\begin{tabular}{|l|l|ll|}
\hline 6. & $\begin{array}{l}\text { Pemberian } \\
\text { saham bonus } \\
\text { dari selisih lebih } \\
\text { revaluasi }\end{array}$ & $\begin{array}{l}\text { a. } \\
\text { b. }\end{array}$ & $\begin{array}{l}\text { Bukan objek pajak sampai dengan jumlah selisih lebih revaluasi secara fiskal. } \\
\text { dalam hal selisih lebih revaluasi secara fiskal lebih besar dibandingkan selisih lebih } \\
\text { revaluasi secara komersial. }\end{array}$ \\
\hline
\end{tabular}

Tabel 3

Ringkasan Ketentuan Peraturan Pemerintah Nomor 34 Tahun 2016

\begin{tabular}{|l|l|l|}
\hline No & \multicolumn{1}{|c|}{ Perihal } & \multicolumn{1}{c|}{ Uraian } \\
\hline 1. & Objek pajak & $\begin{array}{l}\text { Penghasilan yang diperoleh atau diterima dari: } \\
\text { a. pengalihan hak atas tanah dan/atau bangunan; atau } \\
\text { b. perjanjian pengikatan jual beli atas tanah dan/atau bangunan beserta } \\
\text { perubahannya }\end{array}$ \\
\hline 2. & $\begin{array}{l}\text { Bentuk } \\
\text { pengalihan }\end{array}$ & $\begin{array}{l}\text { penjualan, tukar-menukar, pelepasan hak, penyerahan hak, lelang, hibah, waris, atau } \\
\text { cara lain yang disepakati antara para pihak }\end{array}$ \\
\hline 3. & Pengenaan & $\begin{array}{l}\text { a. 2,5\% dikalikan nilai pengalihan } \\
\text { b. } 1 \% \text { dikalikan nilai pengalihan Rumah Sederhana atau Rumah Susun Sederhana yang } \\
\text { dilakukan oleh Wajib Pajak yang usaha pokoknya melakukan pengalihan hak atas } \\
\text { tanah dan/atau bangunan } \\
\text { 0\% atas pengalihan hak atas tanah dan/atau bangunan kepada pemerintah, BUMN, } \\
\text { BUMD yang mendapat penugasan khusus dari pemerintah/kepala daerah } \\
\text { sebagaimana dimaksud dalam undang-undang yang mengatur mengenai } \\
\text { pengadaan tanah bagi pembangunan untuk kepentingan umum }\end{array}$ \\
\hline
\end{tabular}

Tabel 4

Perbedaan Konsep Realisasi Menurut Akuntansi dan UU Pajak Penghasilan

\begin{tabular}{|c|c|}
\hline Konsep Realisasi Menurut Akuntansi & Konsep Realisasi Menurut UU Pajak Penghasilan \\
\hline $\begin{array}{l}\text { a. Realisasi bukan faktor determinan dalam konsep } \\
\text { penghasilan, melainkan hanya berfungsi sebagai } \\
\text { pedoman dalam memutuskan kapan kejadiannya } \\
\text { untuk dicatat dalam pembukuan. } \\
\text { b. Realisasi diartikan secara luas sebagai perubahan } \\
\text { bentuk atau substansi yang signifikan dari aset } \\
\text { dan/atau kewajiban. } \\
\text { c. Perubahan bentuk menuntut adanya transaksi, baik } \\
\text { internal maupun eksternal. } \\
\text { d. Perubahan bentuk baru dapat dicatat dalam } \\
\text { pembukuan jika tingkat ketidakpastiannya sudah } \\
\text { berkurang sampai pada tingkat yang dapat } \\
\text { diterima/sepanjang sudah dapat diukur dengan } \\
\text { uang. }\end{array}$ & $\begin{array}{l}\text { a. Realisasi merupakan faktor determinan dalam } \\
\text { penghasilan. Artinya, begitu terjadi realisasi maka } \\
\text { timbul penghasilan. } \\
\text { b. Realisasi diartikan secara sempit sebagai } \\
\text { perubahan hak atau kepemilikan atau penguasaan } \\
\text { atas aset dan/atau kewajiban, baik aset atau } \\
\text { kewajiban yang sama maupun aset atau kewajiban } \\
\text { yang telah berubah bentuk atau substansi. } \\
\text { c. Perubahan bentuk menuntut adanya transaksi } \\
\text { eksternal. Transaksi internal tidak akan } \\
\text { menimbulkan hak atau kewajiban baru bagi } \\
\text { perusahaan. } \\
\text { d. Pengertian transaksi eksternal atau transaksi } \\
\text { dengan pihak luar entitas menurut UU Pajak } \\
\text { Penghasilan diartikan sebagai transaksi dengan } \\
\text { pihak Subjek Pajak lain. Dalam akuntansi, pihak luar } \\
\text { entitas bisa pihak Subjek Pajak yang berbeda atau } \\
\text { pihak Subjek Pajak yang sama. } \\
\text { e. UU Pajak Penghasilan tidak menentukan bahwa } \\
\text { perubahan hak atas aset ataukewajiban baru dapat } \\
\text { dicatat dalam pembukuan jika aset atau kewajiban } \\
\text { baru dapat dicatat dalam pembukuan jika aset atau } \\
\text { kewajiban itu sudah bisa diukur dan sudah dapat } \\
\text { diuangkan. }\end{array}$ \\
\hline
\end{tabular}




\section{LAMPIRAN GAMBAR}

Gambar 1

Proses untuk Memahami Ketentuan dalam PSAK

\begin{tabular}{|c|c|}
\hline $\begin{array}{l}\text { Kerangka Dasar Penyusunan } \\
\text { Penyajian Laporan Keuangan }\end{array}$ \\
PSAK 16 : Aset Tetap
\end{tabular}

Gambar 2

Proses untuk Memahami Ketentuan dalam Peraturan Perpajakan

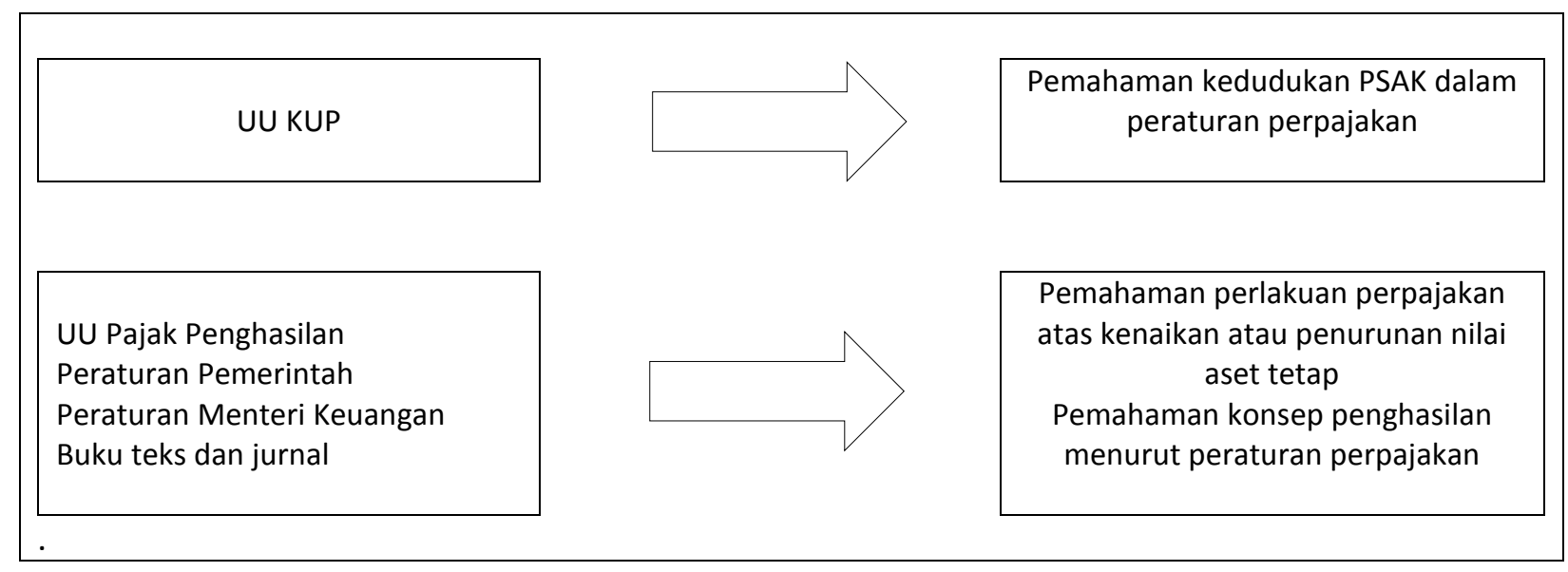

Gambar 3

Proses Analisis Komparatif Perlakuan Akuntansi dan Perpajakan

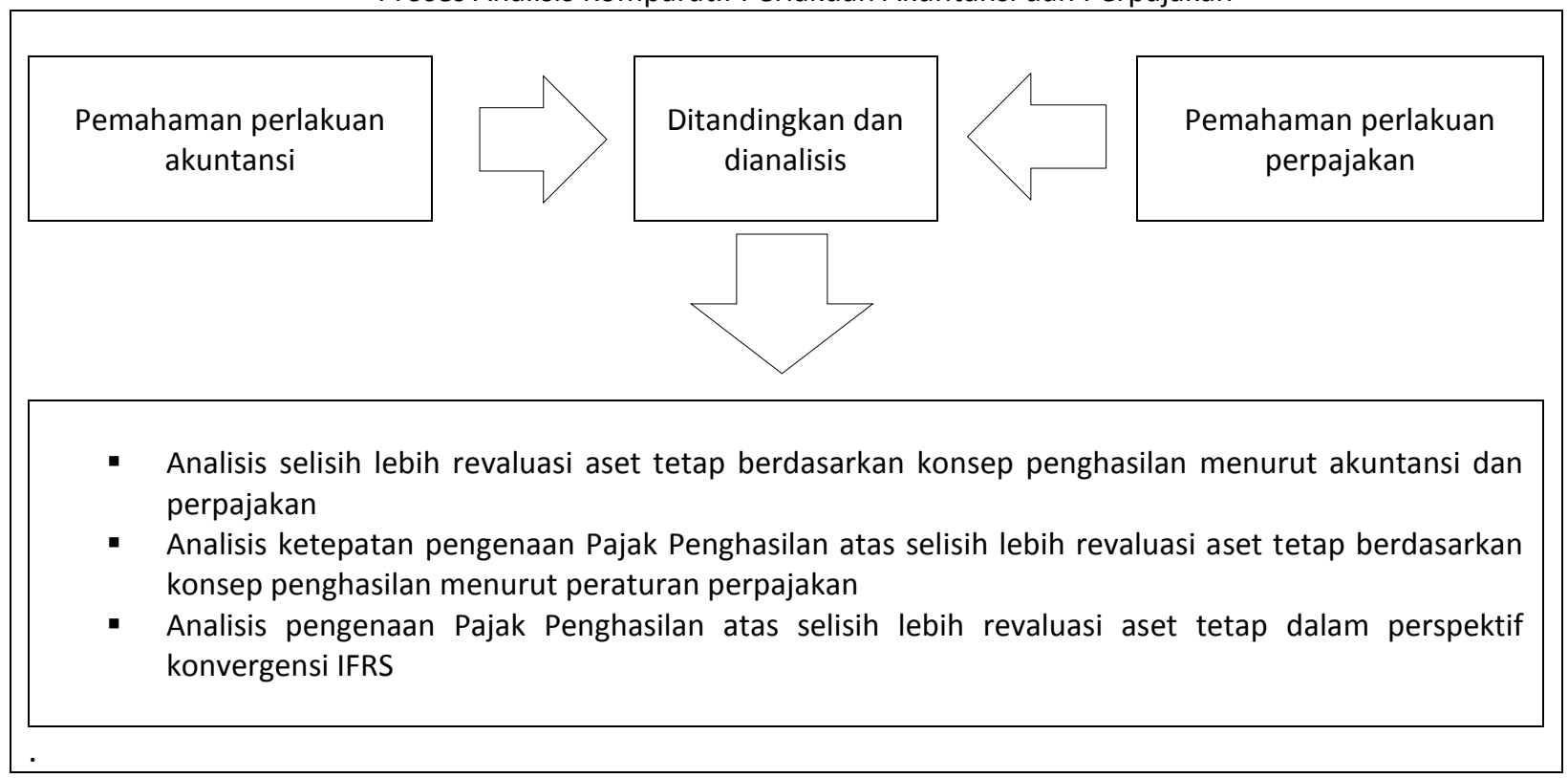


Gambar 4

Pengenaan Pajak Penghasilan atas Selisih Lebih Revaluasi Aset Tetap Berdasarkan Peraturan Perpajakan yang Berlaku

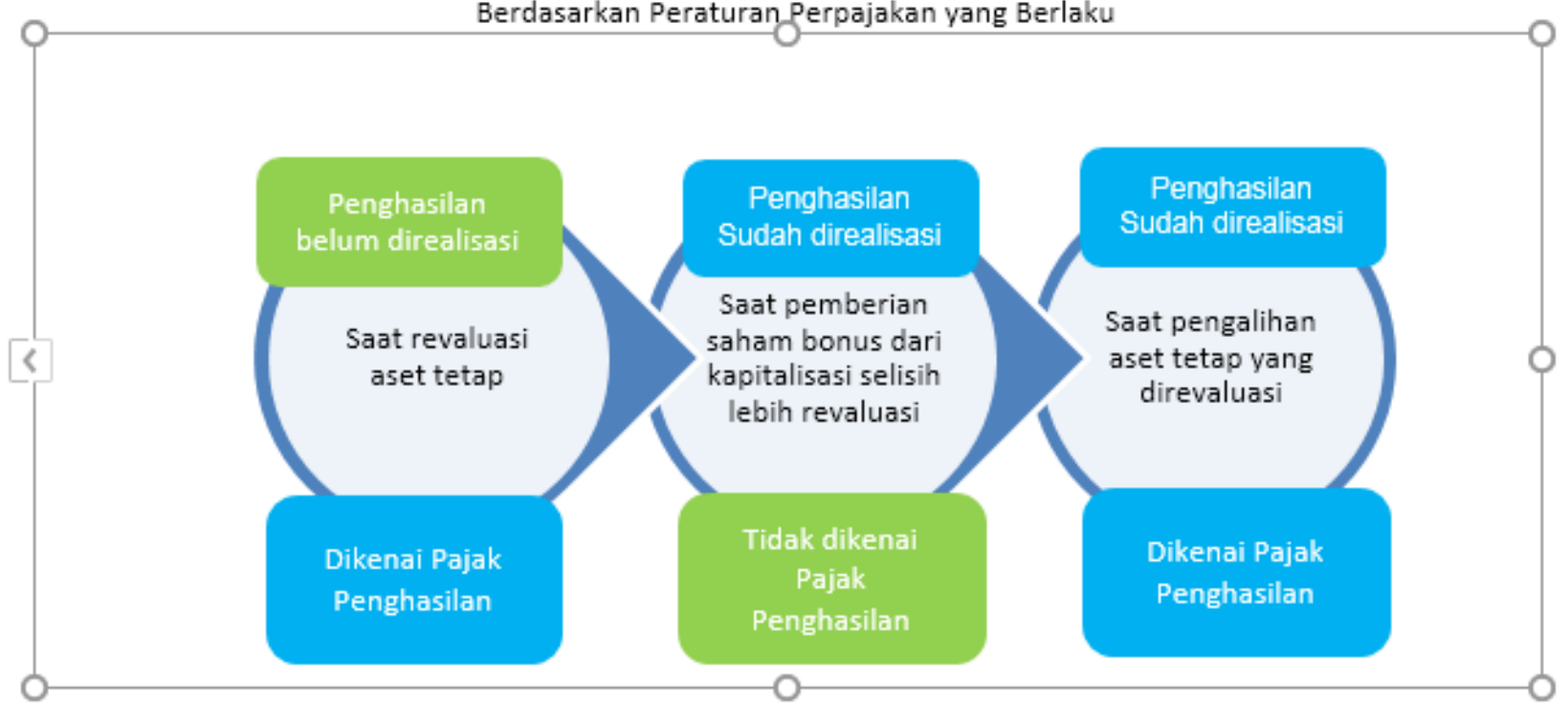

Gambar 5

Pengenaan Pajak Penghasilan atas Selisih Lebih Revaluasi Aset Tetap Berdasarkan Konsep Penghasilan

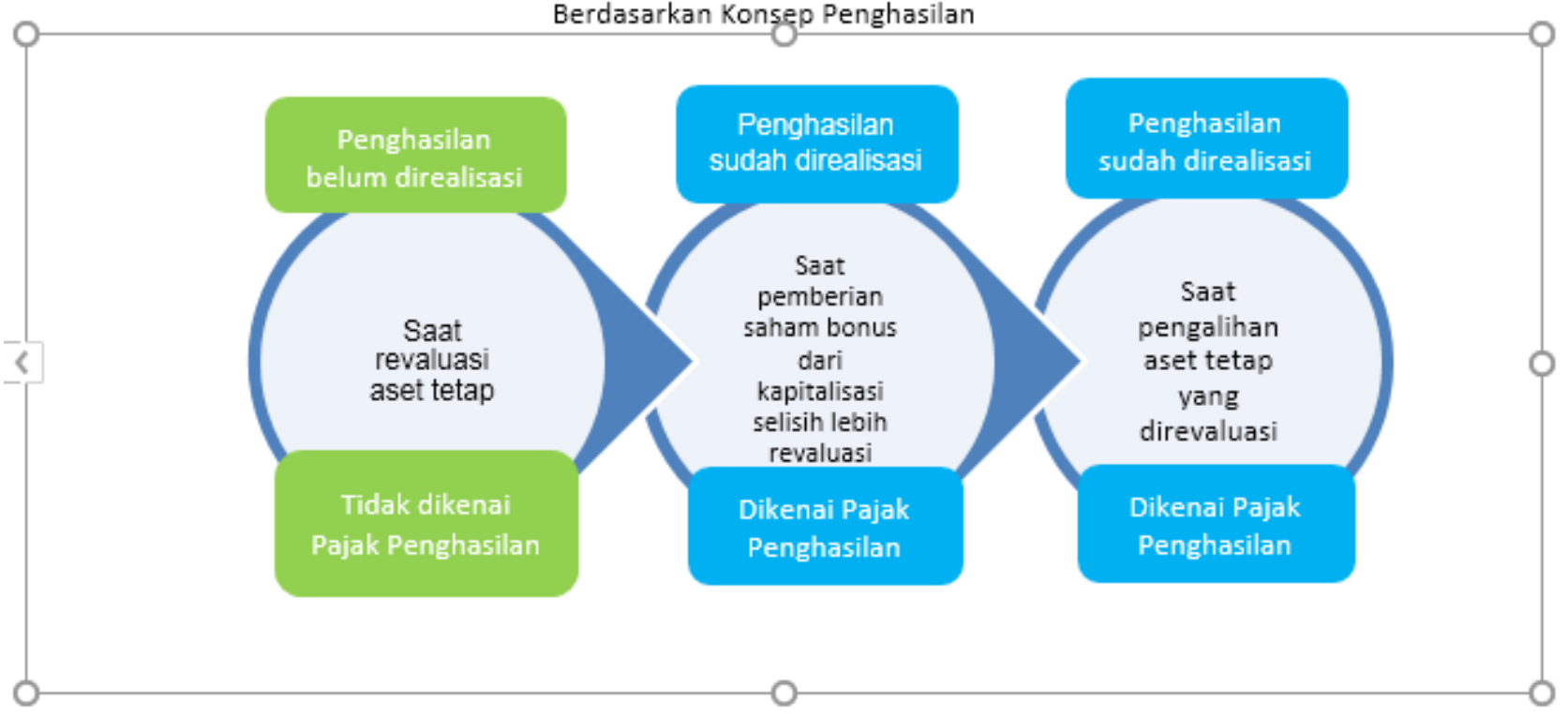

